\title{
ELABORATION OF PRODUCTION TECHNOLOGY OF SEMI-SMOKED SAUSAGES USING LENTIL FLOUR, THYME AND JUNIPER
}

\author{
Iryna Markovych \\ Department of Technology of meat and meat oil and fat products \\ Lviv National University of Veterinary Medicine and Biotechnology named after S. Z. Gzhytsky \\ 50 Pekarska, str., Lviv, Ukraine, 79010 \\ ira.markovuch@yandex.ua \\ Maria Paska \\ Department of Technology of meat and meat oil and fat products \\ Lviv National University of Veterinary Medicine and Biotechnology named after S. Z. Gzhytsky \\ 50 Pekarska, str., Lviv, Ukraine, 79010 \\ maria_pas@ukr.net \\ Iryna Basarab \\ Department of Technology of meat and meat oil and fat products \\ Lviv National University of Veterinary Medicine and Biotechnology named after S. Z. Gzhytsky \\ 50 Pekarska, str., Lviv, Ukraine, 79010 \\ iryna.basarab@mail.ru
}

\begin{abstract}
The complex studies of chemical and biochemical composition of the vegetable raw material were carried out; their influence on technological parameters and microstructure of forcemeat of semi-smoked sausages was detected to prove the expedience of using the spicy-aromatic plants in the production technology of semi-smoked sausages. Antioxidant properties of thyme and juniper were studied. The quality and safety of the new types of semi-smoked sausages were proved on the base of their study by organoleptic, physical-chemical, structural-mechanic, microbiological parameters.

On the base of received results it was persuasively proved the expedience of using the flour of germinated and non-germinated lentil in combination with the meat raw material, especially with chicken, spicy-aromatic plants in composition of semi-smoked sausages, because it favors the improvement of their biological value. Thyme and juniper decelerate the intensity of hydrolysis products creation by $2 \%$ and peroxide creation in the average by $12 \%$ in the studied samples comparing with control. It was determined the maximal storage life of the new types of semi-smoked sausages that is 15 days at temperature $6 \pm 2{ }^{\circ} \mathrm{C}$.

Keywords: semi-smoked sausages, beef, chicken, flour, spicy-aromatic plants, amino acid composition, fatty acid composition, storage life, improvement of quality.

\section{Introduction}

The modern conditions of the market economy need from the producers of food products to introduce the competitive and economically effective technologies at the synchronous improvement of taste characteristics, consumer properties, improvement of quality and food value and at the widening of assortment of the food products. That is why the combination of meat and vegetable raw material is topical in meat products industry.

The main raw material for the sausages production is beef and pork that can manifest the signs of the specific autolysis by the age features of animals, incorrect regimes of feeding and keep, preparation for slaughter [1]. The chicken and vegetable raw material is often used for providing the production of high-quality semi-smoked sausages. The native scientists made a contribution in elaboration of scientific-practical principles of the use of animal and vegetable raw material. In their studies they confirmed the combination of the meat and vegetable raw material in production technologies of the meat products [2-7]. Lentil is widely used for the additional enrichment of products with protein [8].
\end{abstract}


It is possible to improve the taste properties of products and increase the qualitative parameters at the expense of the use of spicy-aromatic plants that is the source of natural antioxidants. The scientific researches in this direction were realized by the foreign scientists, who experimentally proved the influence of nontraditional vegetable raw material on the quality and storage of the meat products [9-13].

Among the large quality of spicy-aromatic plants thyme and juniper are rarely used in production technologies of the meat products. According to the results of biochemical composition of these plants by the scientists S. Stoilova, J. Wanner (2014) [14-16], their bactericidal and antifungal effect was proved and antioxidant properties were confirmed.

That is why elaboration of technologies of the new types of meat products, semi-smoked sausages, using the vegetable raw material of the raised biological and food value is topical and timely.

The aim of research was determination of the optimal conditions of using composition stuffs in semi-smoked sausages production, namely: improvement of production technology of semismoked sausages of beef and poultry using the lentil flour, spicy-aromatic plants thyme and juniper.

\section{Materials and methods}

Determination of the water binding, water keeping and fat keeping abilities was carried out by gravimetric methods as the difference between the mass fraction of water (fat) in forcemeat and quantity of water (fat) that was separated in the process of thermal processing [17, 18]. Amino acid composition of proteins in the vegetable raw material and semi-smoked sausages was determined using the method of ion-exchanging liquid-column chromatography on automatic analyzer of amino acids T 339 manufactured by "Microtechnique", Czechia. Amino acid mixture was determined by the ratio of quantity of correspondent irreplaceable amino acid in $1 \mathrm{~g}$ of protein in sausage and its regulated content in ideal protein by FAO/WHO scale, [19, 20]. Fatty acid composition of the vegetable raw material and semi-smoked sausages was determined by the method of gas-liquid chromatography [21].

The aim of research is the study of the influence of using lentil flour, thyme and juniper on composition and properties of sausage products.

The object of research - the flour of germinated and non-germinated lentil, crushed thyme and juniper, model forcemeats, natural ones and with the use of vegetable raw material, semismoked sausages.

\section{Results of researches}

For determination of expedience of using flour of germinated and non-germinated lentil in production technology of semi-smoked sausages we determined the content of protein, fat, ash, carbohydrates and cellulose in them and their chemical composition was compared with the one of animal raw material.

It was established, that non-germinated and germinated lentil contain $14,1 \pm 0,01 \%$, $16,1 \pm 0,02 \%$ of protein, $0,8 \pm 0,02 \%$ and $16,1 \pm 0,02 \%$ of fat, $2,3 \pm 0,02$ and $2,7 \pm 0,02 \%$ of ash. The raw protein content in lentil is approximated to the protein content in the meat raw material, especially in beef of I quality - 18,90 $\pm 0,61 \%$, pork $-15,89 \pm 0,18 \%$, chicken $-19 \pm 0,01 \%$. The fat content in lentil is less than the one in the meat raw material on the average by $96 \%$, ash $-2,3 \pm 0,02 \%$ and $2,7 \pm 0,02 \%$, that is significantly more than the content in the animal raw material, and cellulose content is $5,4 \pm 0,01 \%$ and $5 \pm 0,01 \%$. Among macroelements in the lentil, the sodium (Na), phosphorus $(\mathrm{P})$, calcium $(\mathrm{Ca})$ content was determined. Non-germinated and germinated lentil contain (mg/100 g) sodium - 0,6 $\pm 0,012$ and $0,53 \pm 0,006$, phosphorus $-0,21 \pm 0,007$ and $0,9 \pm 0,003$, calcium $-0,13 \pm 0,002$ and $0,15 \pm 0,001$. At seed germination the phosphorus $(\mathrm{P})$ and calcium content increases in 5 and 0,06 times, sodium content is 0,07 times less.

The structure and consistence of product change at introduction of the vegetable proteins, especially the flour of germinated and non-germinated lentil, to the forcemeat of semi-smoked sausages. At the choice of quantity of introduced flour the special attention was paid to its appearance and properties. 
At the study of functional-technical parameters of forcemeats using the lentil flour in quantity 1-4\% it was established, that with increase of lentil quantity WKA (water keeping ability), WBA (water binding ability), FKA (fat keeping ability) improve, and provide the minimal losses at the thermal processing. At the examination of the water mass fraction in studied samples after thermal processing it was established, that at using lentil flour in 1-4\% of the meat raw material mass, the water quantity increases from $52,34 \pm 0,13 \%$ to $55,92 \pm 0,1 \%$. The water excess in sausages leads to the worsening of organoleptic and technological parameters, favors the development of microorganisms and accelerate the processes of product spoilage. Taking into account the results of research, the optimal quantity of using both germinated and non-germinated lentil is within 1-2\%, because its positive influence on the quality of finished product, outcome and prevention of losses at thermal processing is proved.

According to the results of the study of chemical composition of spicy-aromatic plants, it was established, that the thyme grass contains protein $-35,5 \pm 0,02 \%$, fat $-1,3 \pm 0,01 \%$, cellulose $-11,4 \pm 0,02 \%$, ash $-10,1 \pm 0,02 \%$ and carbohydrates $-33,2 \pm 0,01 \%$.

In juniper fruits is present the more quantity of essential oils than in thyme grass, that is why the protein fraction is less that is $2,2 \pm 0,01 \%$, fat mass fraction is $9,9 \pm 0,02 \%$, because juniper fruit it is a dry cone-berry that is why the raw cellulose content in it $-5,9 \pm 0,03 \%$. Juniper fruits are characterized with the high content of sugars, so the carbohydrates mass fraction is $72,1 \pm 0,03 \%$ According to the results of comparative characteristic of the chemical composition of thyme and juniper, it was established, that in technologies of the new types of semi-smoked sausages they must be used in quantities $0,08: 0,01 ; 0,07: 0,02 ; 0,06: 0,03 \mathrm{~kg}$ for $100 \mathrm{~kg}$ to avoid the juniper composition influence on the change of organoleptic properties of finished products.

Taking into account the studies of properties of aforesaid vegetable raw material, the production technology of new types of semi-smoked sausages [22] differs from the traditional one by the fact that at the stage of making forcemeat of beef, used in quantity $40 \%$, poultry $-29-28 \%$, the crushed thyme and juniper are introduced in quantities $0,08: 0,01 ; 0,07: 0,02 ; 0,06: 0,03 \mathrm{~kg}$ for $100 \mathrm{~kg}$ that are contained in spicery, they are mixed, lentil flour is added in quantities $1-2 \%$ of the meat raw material, they are mixed and at the final stage the crushed pork brisket is added in quantity $30 \%$.

At the study of composition of semi-smoked sausages, produced by elaborated prescription, their amino acid composition was improved comparing with the control sample of sausage, cooked without using lentil flour, thyme and juniper [22]. It was established, that the fraction of irreplaceable amino acids was essentially increased in the studied products with the use of flour of germinated lentil: "Special Family" (country - producer Ukraine) - 8,498 0 , 1, "Special Sambyrska" (country - producer Ukraine) - 8,568 $\pm 0,11$ and "Special Stryska" - 9,118 $\pm 0,11$ (country - producer Ukraine) [22].

The especially valuable is an essential increase of content of the limited amino acids isoleucine and valinin, which content in sausage "Special Stryska" is $0,754 \pm 0,1$ and $0,81 \pm 0,11$ comparing with other semi-smoked sausages. The mixture of sulfur-containing amino acids methionine+cystine increases from $1,73 \%$ to $7,82 \%$, phenylalanine+tyrosine - from $7,29 \%$ to $10,94 \%$ in semismoked sausages with the flour of germinated lentil [23].

The food value of the new types of semi-smoked sausages depends on content of essential polyunsaturated fatty acids that is more in sausages with the flour of germinated lentil, the ratio of linoleic acid $\left(\mathrm{C}_{18: 2}\right)$ :linolenic acid $\left(\mathrm{C}_{18: 3}\right)>7,0$ in sausages "Special Sambyrska" and "Spicy special Sambyrska" is 11,27 and 11,43.

The grass of common thyme (creeping thyme, Thymus serpyllum) contains up to $1 \%$ of essential oil, phenols, tanning substances, bitterness, gum, saponins, triterpene compounds (ursolic and oleic acids), organic acids (chlorogenic, quinic), flavonoids, mineral salts, expresses anti-inflammatory, antiviral, antibacterial, antifungal, expectorating effects [24].

The fruits of common juniper (Juniperus communis L.) contain essential oil (0,5-2,0\%), flavonoids, pitches $(9 \%)$, pectins, organic acids, sugars $(30 \%)$, tanning substances, potassium salts, have expectorating, anti-inflammatory effects, stimulate the release of gastric juice and bile, improve digestion [25]. 
So far as the spicy-aromatic plants contain the natural components and differ by the chemical composition [26], that allows decelerate the processes of products spoilage, we carried out the study of the changes of quality of the new types of semi-smoked sausages at storage to determine their storage life.

Determination of the free fatty acids (acidity) was carried out by calculating way by the value of acid number. Calculation was made on oleic acid at 10 and 15 days of storage.

The acidity of control sample of semi-smoked sausages after 10 days of storage was $2,76 \%$, and after 15 days of storage increased to $27 \%$. In new types of semi-smoked sausages the acidity was less than in the control sample at 10 day of storage on the average by $1,8 \%$, in 15 days of storage - by $9,5 \%$ (Fig. 1).

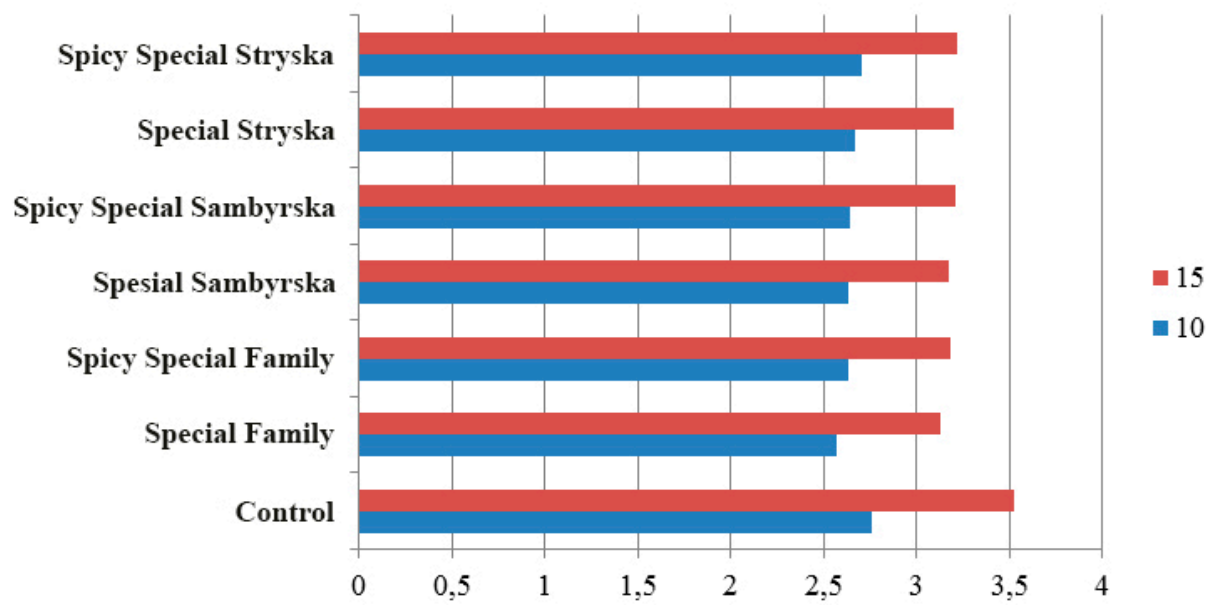

Fig. 1. Content of free fatty acids (acidity), \%, in semi-smoked sausages at 10 and 15 day of storage

In sausages "Special Stryska" and "Spicy Special Stryska" accumulation of the free fatty acids is $2 \%$ comparing with control after 10 days of storage and is decelerated after 15 days of storage by $8,5 \%$, that proves the limitation of free fatty acids accumulation and braking of hydrolysis products creation in semi-smoked sausages with spicy-aromatic plants of thyme and juniper. It is manifested most effectively in sausages with prevailing content of thyme quantity.

At the study of microbiological seeding of sausages depending on storage life it was elucidated, that the dynamic of microflora development in experimental and control samples was negative.

According to the results of researches, the storage life of semi-smoked sausages is 15 days at temperature $+6 \pm 2{ }^{\circ} \mathrm{C}$.

\section{Conclusions}

1. At the study of functional-technological parameters of force meats with using the lentil flour in quantity $1-4 \%$ it was established, that with increase of lentil quantity WKA (water keeping ability), WBA (water binding ability), FKA (fat keeping ability) improve, and provide the minimal losses at the thermal processing. The optimal quantity of lentil flour in sausage products is $1-2 \%$ of the raw material mass.

2. The increased content of irreplaceable amino acids was proved in sausages with flour of non-germinated lentil namely in Special Family" - by 33 \%, in "Special Sambyrska" - by 34 \% and in "Special Stryska" - by $43 \%$ comparing with control. All new types of semi-smoked sausages are characterized with improved biological value.

3. The fatty acid composition of semi-smoked sausages was determined. The highest ratio content of linoleic $\left(\mathrm{C}_{18: 2}\right)$ :linolenic $\left(\mathrm{C}_{18: 3}\right)>7,0$ acids are typical for the sausages "Special Sambyrska" and "Spicy Special Stryska" the ratio of linoleic $\left(\mathrm{C}_{18: 2}\right)$ :oleic $\left(\mathrm{C}_{18: 1}\right)>0,25$ in "Special family" - 0,55.

4. It was experimentally proved, that the influence of the used spicy-aromatic plants decelerates the intensity of hydrolysis products creation by $2 \%$ and peroxides on the average by $12 \%$ 
in studied samples comparing with control. The maximal storage life of the new types of semismoked sausages is determined that is 15 days at temperature $6 \pm 2{ }^{\circ} \mathrm{C}$.

The production of semi-smoked sausages with using the lentil flour, thyme and juniper favors the widening of assortment of products, obtaining of the high-quality sausages. Technological process of their production is long-term one that is why our further researches will be directed on facilitation of sausages production at the expense of shortening of technological stages of production.

\section{References}

[1] Paska, M. (2015). Comparative Quality assessment of NOR, PSE and DFD beef. Eastern-European Journal of Enterprise Technologies, 3 (10 (75)), 59-63. doi: 10.15587/1729-4061.2015.44496

[2] Shtahova, T. A. (2008). Primenenie muki bobovyh kul'tur v tehnologii mjasnyh rublenyh polufabrikatov povyshennoj biologicheskoj cennosti, 1-24.

[3] Maksimov, I. A., Kurchaeva, E. E., Manzhesov, V. I. (2009). Puti racional'nogo ispol'zovanija rastitel'nogo syr'ja pri proizvodstve funkcional'nyh produktov. Sovremennye naukoemkie tehnologii, 4, 20-22.

[4] Kurchaeva, E. E., Maksimov, I. V., Manzhesov, V. I. (2006). Rastitel'nye istochniki belka V kombinirovannyh mjasnyh produktah. Pishhevaja promyshlennost', 1, 90.

[5] Ostrikov, A. N., Vasilenko, V. N., Tatarenkov, E. A., Kopylov, M. V. (2009). Jekstrudirovannye belkovye teksturaty iz zernobobovyh kul'tur. Mjasnaja industrija, 10, 31-33.

[6] Telezhenko, L. M., Atanasov, B. V. (2013). Obgruntuvannya tehnologichnyx pidxodiv kompleksnoyi pererobky sochevyci. Kharchova nauka i tehnologiya, 4 (25), 77-80.

[7] Telezhenko, L. M., Antasova, V. V. (2010). Vplyv proroshhuvannya sochevyci na zminu tehnologichnyh vlastyvostej ta himichnogo skladu produktu. Kharchova nauka i tehnologiya, 4 (13), 70-72.

[8] Martynyuk, I. O. Paska, M. Z. (2013). Vplyv bilkovogo komponenta sochevyci na funkcionalno-tehnologichni pokaznyky kovbasnyh farshiv i gotovyh vyrobiv iz konynoyu. Progresyvna tehnika ta tehnologiyi harchovyh vyrobnycztv, restorannogo ta gotelnogo gospodarstv i torgivli. Ekonomichna strategiya i perspektyvy rozvytku sfery torgivli i poslug, 86-87.

[9] Duh, P.-D., Tu, Y.-Y., Yen, G.-C. (1999). Antioxidant Activity of Water Extract of Harng Jyur (Chrysanthemum morifolium Ramat). LWT - Food Science and Technology, 32 (5), 269-277. doi:10.1006/ fstl.1999.0548

[10] Skocibusic, M., Bezic, N., Dunkic, V. (2006). Phytochemical composition and antimicrobial activities of the essential oils from Vis. growing in Croatia. Food Chemistry, 96 (1), 20-28. doi:10.1016/ j.foodchem.2005.01.051

[11] Yıldırım, A., Mavi, A., Oktay, M., Kara, A. A., Algur, Ö. F., Bilaloğlu, V. (2000). Comparison of Antioxidant and Antimicrobial Activities of Tilia (Tilia Argentea Desf Ex DC), Sage (Salvia Triloba L.) and Black Tea (Camellia Sinensis) Extracts. Journal of Agricultural and Food Chemistry, 48 (10), 5030-5034. doi: 10.1021/jf000590k

[12] Buřričová, L., Andjelkovic, M., Čermáková, A., Réblová, Z., Jurček, O., Kolehmainen, E., Verhé, R., Kvasnička, F. (2011). Antioxidant capacity and antioxidants of strawberry, blackberry, and raspberry leaves. Czech Journal of Food Sciences, 29, 181-189.

[13] Wong, Y.-H., Tan, Ch.-P., Long, K., Nyam, K.-L. (2014). In vitro simulated digestion on the biostability of Hibiscus cannabinus L. seed extract. Czech Journal of Food Sciences, 32, 177-181.

[14] Stoilova, I. S., Wanner, J., Jirovetz, L., Trifonova, D., Krastev, L., Stoyanova, A. S., Krastanov, A. I. (2014). Chemical composition and antioxidant properties of juniper berry (Juniperus communis L.) essential oil. Bulgarian Journal of Agricultural Science, 20 (2), 227-237.

[15] Höferl, M., Stoilova, I., Schmidt, E., Wanner, J., Jirovetz, L., Trifonova, D., Krastanov, A. (2014). Chemical Composition and Antioxidant Properties of Juniper Berry (Juniperus communis L.) Essential Oil. Action of the Essential Oil on the Antioxidant Protection of Saccharomyces cerevisiae Model Organism. Antioxidants, 3 (1), 81-98. doi: 10.3390/antiox3010081 
[16] Ovchinnikov, Ju. A. (1974). Novye metody analiza aminokislot, peptidov i belkov, 120.

[17] Ocenka nekotoryh pishhevyh dobavok: 37-j doklad Ob'edinennogo komiteta jekspertov FAO/VOZ po pishhevym dobavkam serija tehnicheskih dokladov VOZ (1994). Zheneva, 806, 27-38.

[18] Rive, I. F. Skorohod, I. V. (1981). Kolichestvennyj metod opredelenija nekotoryh visokomolekuljarnyh zhirnyh kislot v rostenijah, tkanjah i biologicheskih zhidkostjah organizma sel'skohozjajstvennyh zhivotnyh. Doklady VASHNIL, 8, 32-34.

[19] Kogan, M. B., Pozharskaja, L. S., Ryndina, V. P., Frejdlin, E. M. (1971). Fiziko-himicheskij bakteriologicheskij kontrol' v mjasnoj promyshlennosti, 462.

[20] Antipova, L. V., Rogov, I. A. (2001). Metody issledovanija mjasa i mjasnyh produktov, 376.

[21] Paska, M. Z., Markovych, I. I., Martynyuk, I. O. (2013). Optymizaciya receptury novyh vydiv napivkopchenyh kovbas pry vykorystanni sochevyci ta pryano-aromatychnyh roslyn. Naukovyj Visnyk LNUVM ta BT imeni S.Z. Gzhyczkogo. Seriya «Kharchovi tehnologiyi», seriya «Ekonomichni nauky», 15 (3 (57)), 95-101.

[22] Paska, M. Z., Markovych, I. I. (2014). Funkcionalno-tehnologichni pokaznyky napivkopchenyh kovbas iz chastkovoyu zaminoyu m'yasnoyi syrovyny boroshnom sochevyci. Naukovyj Visnyk LNUVM ta BT imeni S.Z. Gzhyczkogo. Seriya «Kharchovi tehnologiyi», 16 (3 (60)), 119-128.

[23] Halliwell, B. (2006). Polyphenols: antioxidant treats for healthy living or covert toxins? Journal of the Science of Food and Agriculture, 86 (13), 1992-1995. doi: 10.1002/jsfa.2612

[24] Huang, D., Ou, B., Prior, R. L. (2005). The Chemistry behind Antioxidant Capacity Assays. Journal of Agricultural and Food Chemistry, 53 (6), 1841-1856. doi:10.1021/jf030723c

[25] Paska, M., Markovych, I., Simonov, R. (2013). Lentil flour as protein supplement in the production of smoked sausages. Papers of the 6th International Scientific Conference, 68-72. 